JOURNAL OF SECURITY AND SUSTAINABILITY ISSUES

ISSN 2029-7017 print/ISSN 2029-7025 online

2019 September Volume 9 Number 1

http://doi.org/10.9770/jssi.2019.9.1(3)

Scopus

\title{
STRUCTURING ECONOMIC SECURITY OF THE ORGANIZATION
}

\author{
Kateryna A. Pylypenko ${ }^{1}$, Irina V. Babiy ${ }^{2}$, Nelia V. Volkova ${ }^{3}$, Lev K. Feofanov ${ }^{4}$, Nataliia B. Kashchena ${ }^{5}$ \\ 1,3*Poltava state agrarian academy, 1/3 Skovorody Str., Poltava, 36003, Ukraine \\ ${ }^{2}$ Khmelnytskyi National University, Post 11 Instytutska Str., 29016, Khmelnytskyi, Ukraine \\ ${ }^{4}$ Zaporizhzhya National University, Soborny Ave., 226, 69006, Zaporizhzhya, Ukraine \\ ${ }^{5}$ Kharkiv State University of Food Technology and Trade, \\ Klochkivska Square, 333, Kharkiv, 61051, Ukraine Kyiv, Ukraine \\ E-mail: ${ }^{3}$ koaduep@gmail.com
}

Received 10 November 2019; accepted 10 June 2019; published 30 September

\begin{abstract}
The key components in economic security system of the enterprise, which have the greatest influence of factors in external and internal environment are defined. The structuring of strategic economic security of an enterprise as an object of management was done. The structural model of providing comprehensive strategic economic security was proposed. The introduced structural model solves the issue of conceptualization of the economic security architecture and is a unitary system. In providing strategic economic safety of the enterprise it is offered to allocate the presence of an object that is at risk, and the presence of factors that have a threatening effect on the safety of the object as its constituents.
\end{abstract}

Keywords: economic security of the enterprise, external and internal environment, structural security model, strategic position of the enterprise, business process, object of management

Reference to this paper should be made as follows: Pylypenko, K.A.; Babiy, I.V.; Volkova, N.V.; Lev K. Feofanov, L.K.; Kashchena, N.B. 2019. Structuring economic security of the organization, Journal of Security and Sustainability Issues 9(1): 27-38.

http://doi.org/10.9770/jssi.2019.9.1(3)

JEL Classifications: F52, O39

\section{Introduction}

The modern stage of the economy functioning requires a new approach to enterprise management, and the development of such business strategy which would allow the subjects to maintain their competitive advantage for a long term. It is important to ensure stable and highly effective functioning of the enterprise in current conditions, together with the formation of a high potential for its development and growth in the future, it must be provided with economic security.

In modern conditions of management, ensuring economic security of the enterprise is a priority task for any of its organizational and legal forms, the solution of which includes not only the elimination of the threat of crisis phenomena emergence, but also supporting stable and highly effective development, and also the formation of economically safe trajectory of sustainable development. Exactly these states determine the relevance of this study. 


\section{Literature Survey}

The problem of providing and enhancing the economic security of the enterprise is rather widely presented in the scientific works of such scientists as Beer, 1994; Brown, et. al. 2006; D'Agostino, 2008; Dunphy, et. al. 2003; Graham, \&Dodd, 2000; Huber, et. al. 2010; Porter, \&Kramer 2006; Tvaronavičienè et al., 2018; Jankelová et al., 2018; Cherchyk et al., 2019; Limba et al., 2019). But at the same time, we can state, that modern theory and practice of economic security is facing a number of serious problems, related to the lack of essential certainty in long-term (strategic) economic security, insufficient understanding of its key determinants, in the context of which it is necessary to identify the threats in order to eliminate them, which reduces the predictability of the development prospects and the possibility of strategic prediction of the trajectory life cycle of the enterprise. Due to this, research is needed in the context of providing a conceptual apparatus for evaluating economic security and formulating alternative tools for its provision in a long term perspective (Drobyazko S., 2018). The purpose of scientific work is to determine the elements of economic security at the enterprise, to which destructive factors of its external and internal environment are directed and the development of structural model for ensuring the complex strategic economic security.

\section{Methods}

Economic security of the company is a consequence, the result of well-arranged and well-adjusted business processes. Business processes of economic activity are a combination of different types of activities of the enterprise, within which at the beginning of the process ("on the input") used several types of resources, and as a result of the process ("at the exit") a product that represents the value for the consumer is created. According to the process approach, economic security permeates all levels of the organizational structure of the enterprise. The business processes, existing at the enterprise and its influence on the economic safety of the enterprise are studied. Each process on its "exit" is concentrated on achieving the results that ensure the economic security of economic activity.

But there shouldn't be only a process approach to managing economic security, since resources are equally important as a necessary condition for the implementation of various processes, persons who carry out work between "input" and "output" of the process. Thereby, there are methodological prerequisites for using an innovative (cyclical) approach in forming the economic security of an enterprise (Monni et al., 2017).

We can determine the basic principles of the formation of strategic economic security of the enterprise (Arsić, Krstić, 2015; Kalyugina, et. al. 2015):

1. System construction. Management of economic safety of the enterprise should be built as a single interconnected set of elements that provides effective development and implementation of managerial decisions. The formation of such a system involves a clear identification and interconnection of the goals and objectives of management, its objects and subjects, the delineation of levels and functions of management, the choosing of effective mechanisms for the implementation of decisions.

2. Integration with the general enterprise management system. This principle is determined by the fact that the management of economic security is carried out directly through the change of business processes in the field of financial management of the enterprise. This determines the need for organic integration of the economic security management of enterprise with other systems of management of its economic activity and imprints on them.

3. Focusing on the strategic goals of the enterprise development. Whatever the effectiveness of any project management decisions in the field of current protection of economic interests from personal threats, they should be rejected if they conflict with the strategic goals and directions of economic development, undermining the possibility of effective implementation of measures to ensure strategic economic security (Karpenko et. al., 2018). Implementation of this principle is also ensured on the basis of the philosophy of enterprise development, which defines the most important strategic parameters of economic growth of the enterprise and the formation of a system of protection of its priority economic interests in the long-time perspective.

4. Complex character of the formed administrative decisions. All managerial decisions in the field of protect- 
ing the economic interests of the enterprise from external and internal threats are closely interconnected and have a certain effect on the results of its economic activity. In some cases, this action may be controversial. In this regard, the management of economic security should be seen as a comprehensive management system that manages and ensures the development of interconnected, balanced and interrelated management decisions.

5. High dynamism of management. It was established that managerial decisions on ensuring economic security, developed in previous periods, can often not be used repeatedly in the further stages of economic development of the enterprise. This is due to the mobility of the external and internal environment, which forms a new system of threats or the extent of their manifestation. In this regard, the management of economic security should be characterized by high dynamism of response to the adverse effects of factors of the external and internal environment (Kirchner, \& Sperling, 2018).

6. Various approaches to the development of individual management decisions. The implementation of this principle means that the preparation of each managerial decision in the field of economic security of an enterprise should take into account alternative possibilities of action.

7. Adequacy of responding to individual threats to economic interests. The system of economic mechanisms used by the enterprise to neutralize external and internal threats is associated with the cost of financial resources. At the same time, the level of such costs is directly dependent on the number and scale of the use of such mechanisms. Therefore, the inclusion of certain mechanisms for the neutralization of threats to the enterprise's economic security should come from the real level of this threat and be adequate to the costs of its removal (Mayer et al., 2015).

8. Adaptability of the established system of economic security. The enterprise's economic security system must be flexible, adaptable to changing external and internal environments, and the emergence of new interests and new types of threats (Best, 2013).

9. Effectiveness of management decisions that are accepted. Taking into account that it is often difficult to express the effect of managing economic security in monetary terms, the assessment of the effectiveness of certain measures may be comparative.

10. Legitimacy of management decisions that are accepted. Using this principle of economic security management in enterprise implies that the whole system of obtaining the necessary informative data, as well as mechanisms for ensuring protection from the threats, should be legitimate, which means that it should be carried out on the basis of the current legislation and shouldn't contradict the legal acts (Kuril, 2018).

\section{Results}

We can say that consideration of the strategic economic security of an enterprise as an object of management requires the implementation of a certain content-rich decomposition. Levels of decomposition of the economic security at the enterprise as an object of management will be presented in Figure 1. 


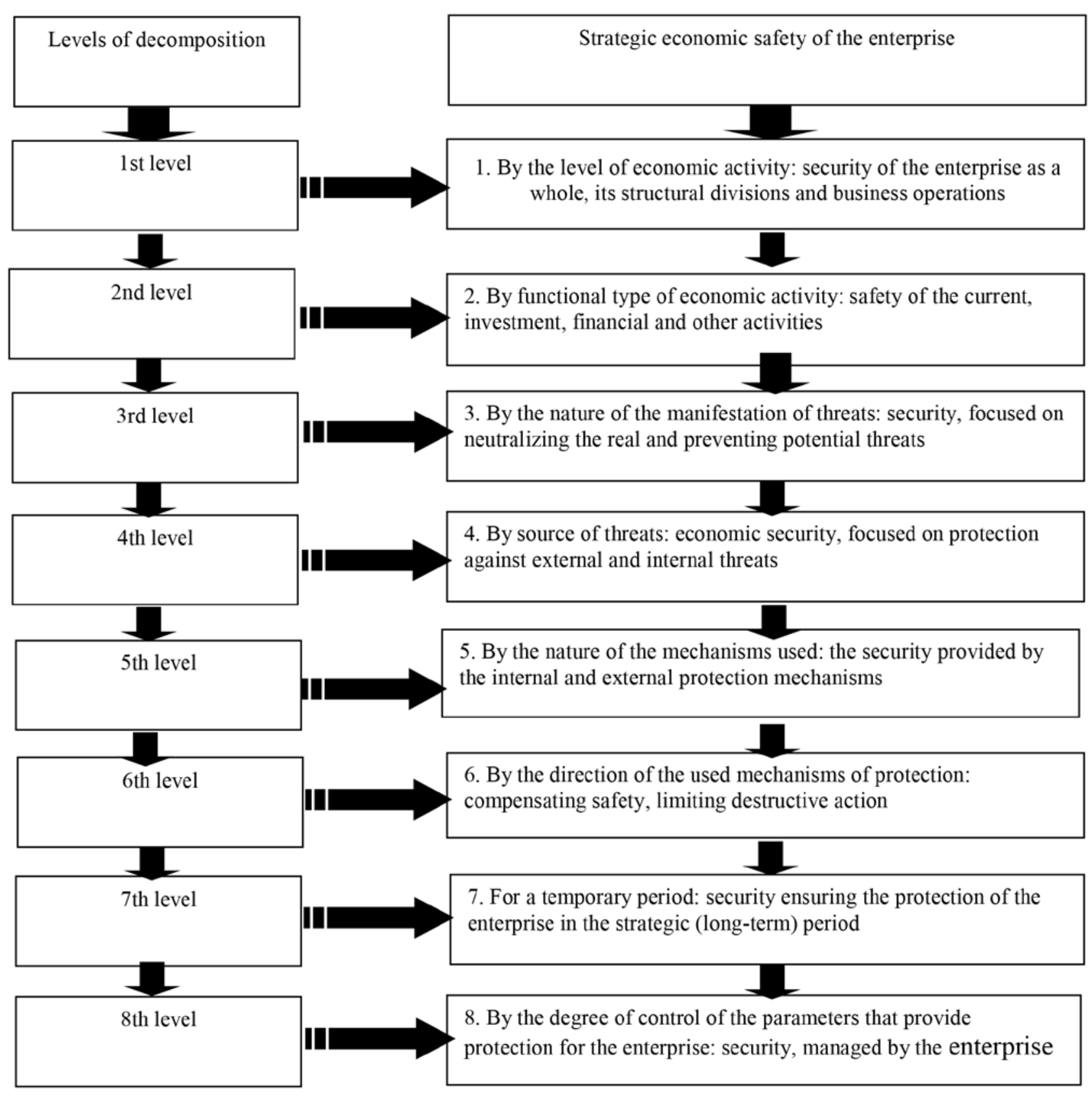

Fig. 1. Decomposition of the strategic economic security of the enterprise

Source: Martensson, \& Westerberg, 2016; McKinsey \& Company, 2011

From this analysis it follows that the strategic economic security of an enterprise is such a state of security of a functioning enterprise (divisions, economic operations), in which the mechanism of protection against real and potential external and internal threats, as a set of interconnected structural elements, ensures its permanent sustainable development and success in reaching the goals in the long-term period (Powell, 2017). 
Table 1. Threats of economic security of the enterprise in terms of business processes of its functioning

\begin{tabular}{|c|c|}
\hline $\begin{array}{l}\text { Business processes } \\
\text { of the enterprise }\end{array}$ & Threats to economic security \\
\hline \multicolumn{2}{|r|}{ Business processes of improvement and development } \\
\hline Strategic management & Incorrect statement of the mission, strategy, purpose of the enterprise, irrational choice of products produced. \\
\hline $\begin{array}{c}\text { Technology } \\
\text { development }\end{array}$ & $\begin{array}{l}\text { Imperfection of existing production technologies, failures in the selection and implementation of new } \\
\text { production technologies. }\end{array}$ \\
\hline Project management & Failure in the selection of projects accepted for implementation at the enterprise. \\
\hline Quality management & Inconsistency of raw materials and products produced with existing quality standards. \\
\hline \multicolumn{2}{|r|}{ Business processes of main activity } \\
\hline $\begin{array}{l}\text { Material and technical } \\
\text { supply and sales }\end{array}$ & $\begin{array}{l}\text { Lack of optimization of volumes and terms of delivery of the order (raw materials and other materials). } \\
\text { Inappropriate pricing policy for the purchase of raw materials, its low quality. }\end{array}$ \\
\hline Production processes & $\begin{array}{l}\text { Crisis of underproduction or overproduction of products. } \\
\text { Moral obsolete production of non-compliance with the terms of production. }\end{array}$ \\
\hline $\begin{array}{l}\text { Marketing activities } \\
\text { and sales }\end{array}$ & $\begin{array}{l}\text { Incorrect definition of the marketing strategy of the enterprise and the positioning of the goods on the market. } \\
\text { Irrational pricing policy. Limited marketing. }\end{array}$ \\
\hline $\begin{array}{l}\text { Service maintenance } \\
\text { by service staff }\end{array}$ & $\begin{array}{l}\text { Ignoring promotional activity. } \\
\text { Violation of after-sales service rules. }\end{array}$ \\
\hline \multicolumn{2}{|r|}{ Auxiliary business processes } \\
\hline $\begin{array}{l}\text { Enterprise } \\
\text { infrastructure support }\end{array}$ & $\begin{array}{l}\text { Mistakes in the development of enterprise development plans. } \\
\text { Unreliable accounting and reporting in the company. }\end{array}$ \\
\hline $\begin{array}{l}\text { Engineering and } \\
\text { technical support }\end{array}$ & Deviations in the mode of operation of the enterprise due to technical malfunctions, defects of fixed assets \\
\hline Information support & Ensuring the preservation and confidentiality of information \\
\hline Workflow & $\begin{array}{l}\text { Inconsistency in the accounting rules of document circulation. } \\
\text { Inaccurate data displaying. } \\
\text { Violation of terms of delivery of the documents }\end{array}$ \\
\hline HR & $\begin{array}{l}\text { Organization of the regime of work and recreation of the personnel } \\
\text { Appointing of the material responsible persons. } \\
\text { Determining the level of access to work and documents. }\end{array}$ \\
\hline
\end{tabular}

Source: Designed by the authors

In order to describe the threats of enterprise economic security in the context of business processes, it is necessary to structure the processes of doing business. One of the most important outcomes of the recent years in the area of the strategy use and enterprise level design systems was the allocation of architectural approach. The actual standard in enterprise architecture is considered a comprehensive model (Wheelen, \& Hunger, 2015), a collection of existing tables, and is used to describe complex corporate and production systems of any type. The concept of enterprise architecture is a way of unifying and synchronizing the functional and business needs of organizations with the capabilities of security systems in the face of their increasing complexity (Drobyazko S., 2019).

The use of an architectural approach is supposed to be applied in business-process management to ensure its strategic economic security. Consideration of the architecture of the enterprise in terms of business processes and the functional component of threats allow the management of the enterprise (organization) to form an idea about the object of security, identify the problem areas most prone to the emergence and effects of the threats, determine the subjects whose actions can lead to their realization, focus on risk assessment methods, tell about possible response times, but most importantly - develop practical measures to ensure economic security (Ianioglo, 2015a).

Business processes of improvement and development, which include: strategic management, technology development, project management, quality management. Business processes for the main business include logistics and sales, production processes, marketing activities and sales, services (Raczkowski, Schneider, 2013). 
Considering this system of business processes as fully describing the activities of the enterprise, the existence of threats to economic security for each separate business operation process should be substantiated (Table 1).

Auxiliary business processes that consist of enterprise infrastructure support, engineering support, information provision, document management and human resources management. Separate components of the strategic economic security of an enterprise can be described in other languages of modeling, using the concepts introduced into a particular structural model of economic security.

These components include contractors, personnel and finance. To the threats of economic security by counterparties is the level of their reliability. The conclusion of various types of transactions, including investment, is an integral part of the functioning of any business. But not always they are successful. In order to minimize the risks of signing "failed" contracts, it is necessary, first of all, to assess the economic soundness of the counterparty. One of the main threats to economic security is the loss of enterprise independence from counterparties, not only legally, but also taking into account the point of view of "removing real content through the use of price mechanisms." Hence, due to institutional problems associated with the organization of cash flows, the redistribution of real capital in favor of counterparties with a more stable and simultaneously more dynamic structure of transactions is carried out (Strielkowski et al., 2016).

The most complete set of threats to the enterprise's economic security by counterparties. We will organize the systematization of such threats based on the characteristics of the counteragent, such as: responsibility, truthfulness, seriousness of partner intentions; information about credit history; managerial and legal aspects of the counterparty's activities; the quality of the proposed cooperation agreement.

At the same time, we propose that one of the main characteristics will be assessing the change in the financial position of the counterparty in the dynamics, which will help to minimize the risk of non-payment, as well as potential investment and credit risks. An explanation for this is the inability of the counterparty to pay off its current debts in the event of a systemic deterioration of its financial situation. Naturally, the company will not be able to pay dividends, which entails the risk of non-receipt of income by the investor. Let us represent this provision in Table 2.

Table 2. Threats of economic security of the enterprise by counterparties

\begin{tabular}{|c|l|}
\hline $\begin{array}{c}\text { Characteristics of } \\
\text { counterparties }\end{array}$ & \multicolumn{1}{c|}{ Threats to economic security } \\
\hline $\begin{array}{c}\text { Responsibility, truthfulness, } \\
\text { seriousness of partnership } \\
\text { intentions }\end{array}$ & $\begin{array}{l}\text { The presence of negative information regarding liability, truthfulness, seriousness of the intentions of } \\
\text { the counterparty. }\end{array}$ \\
\hline Credit history information & $\begin{array}{l}\text { The presence of negative credit history. } \\
\text { Lack of credit history information. }\end{array}$ \\
\hline $\begin{array}{c}\text { Management and legal aspects } \\
\text { of counterparty activity }\end{array}$ & $\begin{array}{l}\text { Involvement of the counterparty in litigation. } \\
\text { activity. } \\
\text { Probability of reorganization of counteragents in the near future. } \\
\text { Likelihood of opening in the near future or actual start of bankruptcy proceedings and (or) liquidation } \\
\text { of the counterparty. } \\
\text { There is an arbitration practice in the counterparty previous periods. }\end{array}$ \\
\hline $\begin{array}{c}\text { The quality of the proposed } \\
\text { cooperation agreement }\end{array}$ & $\begin{array}{l}\text { The poor quality of the cooperation agreement (no essential conditions and guarantees, such as the } \\
\text { maturity of the debt, penalties for non-compliance with the terms of the contract, etc.). } \\
\text { Lack of cooperation agreement (purchase-sale, performance of works, services rendering, lease, etc.) }\end{array}$ \\
\hline $\begin{array}{c}\text { Change in the financial } \\
\text { position of the counterparty's } \\
\text { dynamics }\end{array}$ & $\begin{array}{l}\text { The deterioration of the situation, which causes the insolvency of the counterparty. } \\
\text { Investment risks and credit risks. }\end{array}$ \\
\hline
\end{tabular}


Among the internal threats to the economic security of enterprises that may come from the staff we allocate the following Lasan, 2010):

- insufficient qualification of the employees;

- weak organization of the personnel management system;

- poor organization of the education system;

- ineffective system of motivation;

- reduction of the number of innovative proposals and initiatives;

- the resignation of skilled employees;

- orientation of employees to solve internal tactical tasks;

- orientation of employees to preserve the interests of the unit;

- lack or weakness of corporate policy;

- low-quality screening of candidates for recruitment.

A significant threat to the financial component of the company's economic security is the inadequate control over the structure of the enterprise's investments, the ratio of parts of the financial portfolio to the risk and returns of its components, as well as the low level of control over all aspects of its business, which directly affects the profitability of the business and its growth (Paseková et al., 2017).

A slightly different classification of threats to the economic security of the company on the part of the finance is proposed to be used for the purpose of their full identification in the construction of a company's security system. The classification of the types of threats to the financial component of economic security (Belas et al. 2017) in the context of the proposed classification features is presented in Table 3.

Table 3. Threats to the economic security of the enterprise on the part of finance

\begin{tabular}{|c|c|}
\hline Classification mark & Types of threats to the financial component of economic security \\
\hline Level of financial activity & $\begin{array}{l}\text { Threats of financial activity to the enterprise as a whole. } \\
\text { Threats of financial activity of separate structural divisions (centers of responsibility) of the enterprise. } \\
\text { Threats of financial activity on realization of separate economic operations of the enterprise. }\end{array}$ \\
\hline $\begin{array}{l}\text { Functional type } \\
\text { of financial activity }\end{array}$ & $\begin{array}{l}\text { Threats that manifest themselves in the sphere of investment activity of the enterprise. } \\
\text { Threats that appear in the area of lending activity of the enterprise. } \\
\text { Threats that are manifested in the field of emission activity. } \\
\text { Threats that are manifested in innovation. } \\
\text { Threats that manifest themselves in the field of other types of financial activity of the enterprise. }\end{array}$ \\
\hline Object orientation & $\begin{array}{l}\text { Threats to financial operations of the enterprise. } \\
\text { Threats to the assets of the enterprise. } \\
\text { Threats to the company's financial information. } \\
\text { Threats to financial technologies of the enterprise. } \\
\text { Threats to financial personnel (financial managers) of the enterprise. }\end{array}$ \\
\hline $\begin{array}{l}\text { The character of } \\
\text { manifestation }\end{array}$ & $\begin{array}{l}\text { Real Threats. } \\
\text { Potential threats. }\end{array}$ \\
\hline Sources of origin & $\begin{array}{l}\text { External threats. } \\
\text { Internal threats. }\end{array}$ \\
\hline Nature of origin & $\begin{array}{l}\text { Threats generated by the action of objective factors and conditions. } \\
\text { Threats generated by the actions of the entities of the financial relations of the enterprise. }\end{array}$ \\
\hline Time period & $\begin{array}{l}\text { Current threats. } \\
\text { Long-term threats. }\end{array}$ \\
\hline $\begin{array}{l}\text { Level of probability } \\
\text { of implementation }\end{array}$ & $\begin{array}{l}\text { Threats with low probability. } \\
\text { Medium probability threats. } \\
\text { Threats with high probability. } \\
\text { Threats that can not be identified. }\end{array}$ \\
\hline $\begin{array}{l}\text { The size of the possible } \\
\text { damage }\end{array}$ & $\begin{array}{l}\text { Threats with permissible level of damage. } \\
\text { Threats with critical level of damage. } \\
\text { Threats with catastrophic damage. }\end{array}$ \\
\hline Possibility of foreseeability & $\begin{array}{l}\text { Predictable threats } \\
\text { Unpredictable threats }\end{array}$ \\
\hline
\end{tabular}


Hence, among the main threats to the strategic economic security of the enterprise, from a key determinant such as finance, it is proposed to allocate (Ianioglo \& Polajeva 2017b; Mason et al. 2013):

- threat of loss of liquidity of the enterprise;

- threat of loss of financial independence of the enterprise;

- threat of the reduction of the efficiency of the enterprise, loss of its profitability and the ability to self-purchase and development;

- threat of aging of fixed assets due to the "transfer" of the depreciation fund;

- threat of unstable enterprise development;

- threat of debt build-up as a result of slowing down the collection of receivables;

- threat of using ineffective credit policy in relation to receivables and payables;

- threat of insolvency of the enterprise;

- threat of reduction of profitability and market value of the enterprise;

- threat of destruction of the value of the enterprise.

As a result of the transformation of threats to the economic security of the enterprise on its components we have found that the threats emanating from the staff, the organization of finance and counterparties completely duplicate the risks of inefficient organization of business processes of the enterprise.

Having determined the system of threats of strategic economic security of the company and also proposing a list of its key determinants on their basis, it seems that the next stage of the research program implementation is the development of methods and indicators to assess the threats emanating from the components of strategic economic security by reducing the internal and external threats of the economic security of the enterprise to the determinants of the micro level (business processes), and the latter, in turn, to resource-determinants of strategic economic (personnel, finances and contractors), as well as the substantiation of the existence of different levels of economic security.

Having substantiated the theoretical basis for the formation of strategic economic security of an enterprise, it seems to be possible for us to develop its structural model. Such a model allows the development of "mobile" systems that respond to changes in the external and internal environment. It establishes contours of response and stable positions. Ontological models solve the problem of conceptualization of the subject areas of the enterprise on the upper levels of architecture and the representation of interconnected business models in a single system (Choi et al., 2017).

Economic security of an industrial enterprise is a continuous process of provision at an industrial enterprise that is in a certain external environment, the stability of its functioning, financial equilibrium and regular profit extraction, as well as the ability to accomplish its goals and objectives, its ability to further develop and improve at various stages in the life cycle of the enterprise and in the process of changing competitive market strategies.

This definition considers economic security as a process that takes into account both the change in the state of the enterprise and the impact of its external environment. Figure 1 shows an approach to analyzing the levels of external and internal threats affecting the economic security of industrial enterprises.

This analysis shows that enterprises in solving the problem of ensuring economic security are able to manage threats to level I, take into account and predict changes in level 1 threats and take actions to reduce the corresponding damage. Level 1 threats are the most serious and least predictable for the enterprise (Bhatia, \& Thakur, 2017). Herewith, security of the same object can be carried out by different entities, each at its own level. Having determined in the process of diagnosis by the key indicators of the components the level of economic security of the enterprise, it seems necessary to develop entities of the mechanism for the adoption of management decisions to ensure a high level of strategic economic security of the enterprise, the result of which must be defined strategies for enterprise development (Makedon, et al., 2018). 


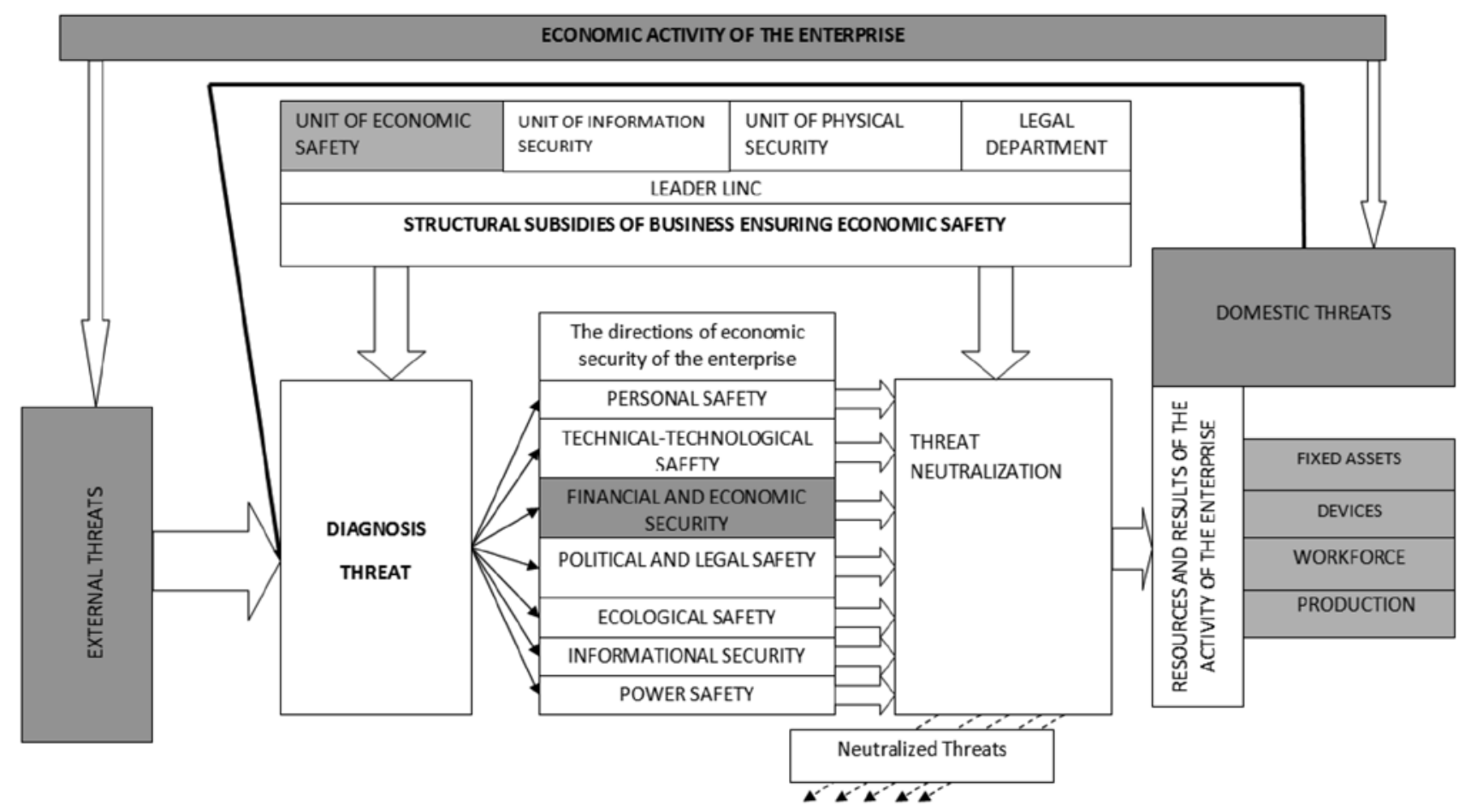

Fig. 1. Structural model of economic security of the enterprise

Source: Designed by the authors

\section{Discussion}

At the same time, the process of diagnostics, detection, recognition of threats to the economic security of the enterprise, should be under constant control of process monitoring. The mechanism for making managerial decisions to ensure a high level of strategic economic security of an enterprise, as well as developing a strategy for enterprise development, taking into account its level of economic security, must be supported by process control.

Thus, the company's economic security should be ensured, first of all, due to the effective internal structure and organization of the company's activities. That means, that along with protective measures implemented by the enterprise, it must protect itself on the basis of high productivity.

In determining the level of economic security, it is necessary to introduce the concept of "Threshold value of the indicator of the component of economic security". This is the significance in which the level of economic security of an industrial enterprise changes in one of the components of economic security Depending on the value of the deviation of the indicator of the component of economic security, according to experts from its threshold value, the level of economic security of an industrial enterprise is proposed to be characterized as:

a) normal - when the actual values of all the indicators of the components of economic security are between the threshold values and values equal to 1 ;

b) pre-crisis - when the actual values of two or three indicators of the components of economic security become less than their threshold values;

c) crisis - when the actual value of the most indicators of the components of economic security becomes less than their threshold values;

d) critical - when all (or almost all) actual values of indicators for the components of economic security become less than their thresholds (Fjord Trends, 2019). 
It is important to emphasize that the highest degree of security is achieved thanks to the fact that the whole set of indicators is within the limits of their thresholds, and the threshold values of one indicator are achieved not to the detriment of others. Therefore, it can be concluded that outside the threshold values, the enterprise loses its ability to dynamic self-development, competitiveness and, consequently, is doomed to financial failure and bankruptcy.

Continuous reduction of the level of economic security can be carried out systematically, taking into account: the maximum permissible level of reduction of economic activity, volume of production, investment and financing, as well as increase of efficiency of economic activity and further development on the technical level, innovation, investment, personnel and qualification potential.

\section{Conclusions}

It was proved that the process approach in its traditional sense is inappropriate for managing strategic economic security, since resources are no less important as a necessary condition for the implementation of various processes, those who carry out work between the "input" and the "exit" of the process, and also counterparties, who can stop the process.

The expediency of synthesis process (impact of business processes existing in the enterprise on the economic security of enterprises) and cyclic approach, which allows to identify threats in the context of the determinants of enterprise security on the micro level (business processes and resources), were determined.

The structural model for ensuring the strategic economic security of the enterprise was proposed. It discloses the content of the process done by the providing subject for the object thanks to the implementation of a set of directions and measures formed on the basis of monitoring the threats and assessing the level of security. The structural model is applicable on various levels of detailing from the upper level of description of the basic categories of economic security management to the level of designing analytical applications, and can describe various aspects of strategic security - from the system of strategies and goals to the organizational structure and business processes. In the system, as components of strategic economic security at enterprises, there are an object that is at risk, factors that threaten the safety of the object, the subject that provides security.

\section{References}

Arsić, M. and Krstić, G. (2015). Effects of Formalisation of the Shadow Economy. Berlin: Springer International Publishing, pp.101-106.

Beer, S. (1994). The heart of enterprise. JohnWilley \& Sons

Belas J. Misankova, M., Schönfeld, J., Gavurova, B. (2017). Credit risk management: Financial safety and sustainability aspects, Journal of Security and Sustainability Issues 7(1): 79-94. http://dx.doi.org/10.9770/jssi.2017.6.1(7)

Best, R.J. (2013). Market-based management (Sixth Edition). Strategies for growing customer value and profitability.

Bhatia, A., \& Thakur, A. (2017). Choice of diversification strategies in an emerging market environment: An empirical evaluation. International Journal of Business and Globalization, 19(1): 52-78.7

Brown, A.C., Stern, J., Tenenbaum, B., \& Gencer, G. (2006). Handbook for Evaluating Infrastructure Regulatory Systems. Washington: World Bank.

Cherchyk, L., Shershun, M., Khumarova, N., Mykytyn, T., Cherchyk, A. 2019. Assessment of forest enterprises' performance: integrating economic security and ecological impact, Entrepreneurship and Sustainability Issues 6(4): 1784-1797. http://doi.org/10.9770/ jesi.2019.6.4(17)

Choi, T. M., Chan, H. K., \& Yue, X. (2017). Recent development in big data analytics for business operations and risk management. IEEE transactions on cybernetics, 47(1): 81-92. URL: https://ieeexplore.ieee.org/abstract/document/7378465

D’Agostino, D. (2008). Defense Critical Infrastructure: Risk Analysis of Critical Infrastructure Omits Highly Sensitive Assets. Washington: US Gout Accountability Office. 
Drobyazko S. (2018). Features of the GE/McKinsey model application for assessing the positions as a factor of security of insurance enterprises. International scientific journal "Internauka". Series: "Economic Sciences". №10 (18). - 78 c. - P. 9-11. https://doi. org/10.25313/2520-2294-2018-10-4788

Drobyazko S. (2019). Results of introduction of the improved mechanism of economic security control of insurance companies // International scientific journal "Internauka". Series: “Economic Sciences”. №1. - 78 c. - P. 9-11. https://doi.org/10.25313/2520-22942019-1-4783

Dunphy, D., Griffiths, A., Benn, S. (2003). Organizational Change For Corporate Sustainability: a Guide For Leaders and Change Agents of The Future, Routledge, London.

Fjord Trends 2019, a report that examines seven trends shaping business, technology, and design. One of the seven: Data Minimalism. For more information, Available on the Internet: https://www.fjordnet.com/conversations/fjord-launches-2019-trends-report/

Graham, B., \& Dodd, D. (2000). Security Analysis. The Classic 1934. New York: The McGraw-Hill Companies, Inc.

Huber, G., Rehm, P., Schlesinger, M., Valletta, R. (2010). Economic Security at Risk: Findings from the Economic Security Index.

Ianioglo, A. (2015a). Comprehensive system of ensuring the economic security of enterprise, Agricultural and Resource Economics: International Scientific E-Journal 1(1): 69-79.

Ianioglo Alina \& Polajeva Tatjana (2017b). Innovative component of economic security of enterprises: a case of the Republic of Moldova, Journal of Business Economics and Management, 18(6): 1228-1242, https://doi.org/10.3846/16111699.2017.1405365

Jankelová, N., Jankurová, A., Beňová, M., Skorková,Z. (2018). Security of the business organizations as a result of the economic crisis. Entrepreneurship and Sustainability Issues 5(3): 659-671. http://doi.org/10.9770/jesi.2018.5.3(18)

Kalyugina, S., Strielkowski, W., Ushvitsky, L., Astachova, E. (2015). Sustainable and secure development: facet of personal financial issues. Journal of Security and Sustainability Issues 5(2): 297-304. https://doi.org/10.9770/jssi.2015.5.2(14)

Karpenko, L., Serbov, M., Kwilinski, A., Makedon, V. \& Drobyazko, S. (2018). Methodological platform of the control mechanism with the energy saving technologies. Academy of Strategic Management Journal 17(5) URL: https://www.abacademies.org/articles/ Methodological-platform-of-the-control-mechanism-1939-6104-17-5-271.pdf

Kirchner E., \& Sperling, J. (2018). EU security governance. URL: https://www.manchesterhive.com/view/9781526130945/978152613 0945.xml

Kuril, J. (2018). Public administration for safe and secure environment: case of Slovak Republic, Entrepreneurship and Sustainability Issues 5(3): 493-501. https://doi.org/10.9770/jesi.2018.5.3(6)

Lasan, N. (2010). Security: concepts in contemporary society. Revista de Administrație Publică și Politici Sociale, An II, Nr. 4(5): 39-50.

Limba, T., Stankevičius, A., Andrulevičius, A. 2018. Industry 4.0 and national security: the phenomenon of disruptive technology, Entrepreneurship and Sustainability Issues 6(3): 1328-1335. https://doi.org/10.9770/jssi.2019.6.3(33)

Makedon, V., Valikov, V., Kurinnaya, I. (2018). Transitional strategies of organizational change and integration transformations for industrial enterprises, Academy Review 2(49): 31-44. https://doi.org/10.32342/2074-5354-2018-2-49-3

Mason, C. N., Salas, D., Ebanks, J. K. Bowser (2013). Economic Security and Well-Being Index. For Women in New York City, The New York Women's Foundation, New York.

Martensson K., \& Westerberg, K. (2016). Corporate environmental strategies towards sustainable development. Business Strategy and the Environment, 25(1), 1-9. URL: https://onlinelibrary.wiley.com/doi/full/10.1002/bse.1852

Mayer, N., Grandry, E., Feltus, C., Goettelmann, E. (2015). Towards the entry framework: Security risk management enhanced by the use of enterprise architectures. Lecture Notes in Business Information Processing, 36: 459-469.

McKinsey \& Company (2011). The business of sustainability: McKinsey Global Survey results, McKinsey \& Company.

Monni, S., Palumbo, F., Tvaronavičienè, M. (2017). Cluster performance: an attempt to evaluate the Lithuanian case, Entrepreneurship and Sustainability Issues 5(1): 43-57. https://doi.org/10.9770/jesi.2017.5.1(4)

Porter, E., \& Kramer, R. (2006). Strategy and Society the Link Between Competitive Advantage and Corporate Social Responsibility. Harvard Business Review, 76-93. 
Paseková, M., Svitáková, B., Kramná, E., Otrusinová, M. (2017). Towards financial sustainability of companies: issues related to reporting errors, Journal of Security and Sustainability Issues 7(1): 141-153.

Powell, T.C. (2017). Strategy as diligence: Putting behavioral strategy into practice. California Management Review, 59(3): 160-190.

Raczkowski, K., Schneider, F. (2013). The economic ecurity of Business Transactions. Management in business. Oxford: Chartridge books.

Strielkowski, W.; Lisin, E.; Tvaronavičienė, M. (2016). Towards energy security: sustainable development of electrical energy storage. Journal of Security and Sustainability Issues 6(2): 43-52. http://dx.doi.org/10.9770/jssi.2016.6.2(4)

Tvaronavičienė, M., Masood, O., Javaria, K. (2018). Preconditions of the Eurozone economic security: how to overcome liquidity risk and cost inefficiency in leading banks of UK and Germany. Polish journal of management studies 18(1): 418-427. http://dx.doi. org/10.17512/pjms.2018.18.1.31

Wheelen, T.L. \& Hunger, J.D. (2015). Strategic management and business policy: Concepts (Fourteenth Edition). Pearson/Prentice Hall.

Kateryna A. PYLYPENKO, D.Sc. in Economics, associate professor at the department of the organization of accounting and audit, Poltava State Agrarian Academy

ORCID ID: orcid.org/ 0000-0003-3170-1208

Irina V. BABIY, PhD in Economics, Associate Professor of the Department of Economics, Management and Administration of the Khmelnytskyi National University

ORCID ID: orcid.org/0000-0001-5644-6704

Nelia V. VOLKOVA, PhD in Economics, senior lecturer at the department of enterprise economics, Poltava State Agrarian Academy ORCID ID: orcid.org/0000-0002-8374-1546

Lev K. FEOFANOV, Candidate of Economic Sciences (Ph.D.), Associate Professor, Associate Professor at the Department of Accounting, Analysis, Taxation and Audit, Zaporizhzhya National University

ORCID: ID: orcid.org/0000-0002-0753-7412

Nataliia B. KASHCHENA, Ph.D. (Econ.), Associate Professor, Professor at the Department of Finance, analysis and insurance, Kharkiv State University of Food Technology and Trade

ORCID ID: https://orcid.org/0000-0002-9714-5438

Register for an ORCID ID:

https://orcid.org/register

This work is licensed under the Creative Commons Attribution International License (CC BY)

http://creativecommons.org/licenses/by/4.0/ 